\title{
Developing A Family-Size Biogas-Fueled Electricity Generating System
}

\author{
Agus Haryanto ${ }^{a}$, Fadli Marotina, Sugeng Triyono ${ }^{a}$, Udin Hasanudin ${ }^{\mathrm{b}}$ \\ ${ }^{a}$ Department of Agricultural Engineering, Faculty of Agriculture, the University of Lampung, Bandar Lampung, 35144, Indonesia. \\ ${ }^{b}$ Department of Agro-industrial Technology, Faculty of Agriculture, the University of Lampung, Bandar Lampung, 35144, Indonesia.
}

\begin{abstract}
The purpose of this study is to develop a family-size biogas-fueled electricity generating system consisting of anaerobic digester, bio-filter scrubber, and power generating engine. Biogas was produced from a pilot scale wet anaerobic digester (5- $\mathrm{m}^{3}$ capacity). The biogas was filtered using bio-scrubber column filled with locally made compost to reduce hydrogen sulfide $\left(\mathrm{H}_{2} \mathrm{~S}\right)$ content. Biogas composition was analysed using a gas chromatograph and its $\mathrm{H}_{2} \mathrm{~S}$ level was measured using a $\mathrm{H}_{2} \mathrm{~S}$ detector. A $750-\mathrm{W}$ four stroke power generating engine was used with $100 \%$ biogas. Biogas consumed by the generator engine was measured at different load from 100 to $700 \mathrm{~W}$ (13.3 to $93.3 \%$ of the rated power). Three replications for each load experiment were taken. Results showed that the total biogas yield was $1.91 \mathrm{~m}^{3} /$ day with methane content of $56.48 \%$ by volume. Bio-filter successfully reduced $\mathrm{H}_{2} \mathrm{~S}$ content in the biogas by $98 \%$ (from $400 \mathrm{ppm}$ to $9 \mathrm{ppm}$ ). Generator engine showed good performance during the test with average biogas consumption of $415.3 \mathrm{~L} / \mathrm{h}$. Specific biogas consumption decreased from 5.05 $\mathrm{L} / \mathrm{Wh}$ to $1.15 \mathrm{~L} / \mathrm{Wh}$ at loads of $100 \mathrm{~W}$ to $700 \mathrm{~W}$, respectively. Thermal efficiency increased with loads from $6.4 \%$ at $100 \mathrm{~W}$ to 28.1 at $700 \mathrm{~W}$. The highest thermal efficiency of $30 \%$ was achieved at a load of $600 \mathrm{~W}(80 \%$ of the rated power) with specific biogas consumption of $1.07 \mathrm{~L} / \mathrm{Wh}$.
\end{abstract}

Keywords: biogas; family size; generator; electricity; bio-filter.

Article History: Received Janury 16 ${ }^{\text {th }}$ 2017; Received in revised form $2^{\text {nd }}$ June 2017; Accepted $18^{\text {th }}$ June 2017; Available online How to Cite This Article: Haryanto, A., Marotin, F., Triyono, S., Hasanudin, U. (2017), Developing A Family-Size Biogas-Fueled Electricity Generating System. International Journal of Renewable Energy Development, 6(2), 111-118.

https://doi.org/10.14710/ijred.6.2.111-118

\section{Introduction}

In 2015 electrification ratio in Indonesia has reached $88.30 \%$, increasing $3.94 \%$ from the previous year (Directorate General of Electricity, 2016). This number, however, is still lower as compared to other ASEAN countries such as Malaysia (99.4\%), Singapore (100\%), Thailand (99.3\%), the Philippines (89.7), or Vietnam (97.3\%) (Power in Indonesia, 2015). The implication of this condition is that around $12 \%$ of Indonesian people (about 29.8 million or around 7.46 million household) have no access to electricity grid. In general, these people are living in remote and sparsely populated areas or small islands. Such areas are characterized by the absence of industrial activity, poor infrastructure and are geographically not covered by the electricity distribution network (off grid) from Government-owned Electricity Company or PLN. This problem is accentuated by a fact that Indonesia consists of about 13,000 islands. Assuming each unelectrified household requires electricity supply of 450 VA (the lowest of existing power rate from PLN's grid), and all power plants for supplying it operate at $80 \%$ of their name plate capacity, then it will require approximately $4.2 \mathrm{GW}$ new additional power to cover just households in remote areas. The Power Supply Business Plan (RUPTL) 2015-2024 plans to develop $70,7 \mathrm{GW}$ for the next 10 years (PLN, 2015). This means an average growth rate of $7 \mathrm{GW}$ per annum.

Some communities (mostly in remote areas and on small islands) have generated their own electricity using small generator engines. This option, however, is not environmentally friendly. Oil fuels happen to more and more difficult and are not available in remote areas. Electricity price using this option is

\footnotetext{
* Corresponding author: agus.haryanto@fp.unila.ac.id
} 
Citation: Haryanto, A., Marotin, F., Triyono, S., and Hasanudin, U. (2017), Developing A Family-Size Biogas-Fueled Electricity Generating System. International Journal of Renewable Energy Development, 6(2), 111-118, https://doi.org/10.14710/ijred.6.2.111-118

$\mathrm{P}$ a g e | 112

much more expensive. At a non-subsidized diesel fuel price of $9,400 \mathrm{IDR} / \mathrm{L}$ and engine efficiency of $30 \%$, the cost of electricity is around $3,100 \mathrm{IDR} / \mathrm{kWh}$ just to cover fuel consumption. In more remote areas the electricity price using diesel generators will be much more expensive as compared to current electricity price of 1,509.38 IDR/kWh for R1-TR connection type (PLN, 2015).

Remote and sparsely populated areas in Indonesia will be best powered up by locally available renewable energy using economically efficient and proven technologies, such as: biomass, microhydro, or biogas power. Biogas can be one of the reliable solutions to generate electricity in remote areas. Raw materials or substrates for biogas can be developed locally and cheaply such as cow dung, agricultural wastes or dedicated crops. Production of biogas from renewable feedstock, such as energy crops and agro-industrial wastes through anaerobic digestion process could substitute fossil fuel-derived energy and reduce greenhouse gas emission (Chynoweth et al., 2001). Regarding the socio-economic features of villagers in less developed countries, the biogas produced from renewable sources is the right option and could play a major role in meeting both energy and environmental problems (Kabir et al., 2013). Based on a thorough parametric analysis, Chandra et al. (2012) concluded that the production of methane (biogas) from lignocellulosic biomass of agricultural waste is more economically and environmentally advantageous and is a sustainable way to produce energy from biomass. Biogas produced from anaerobic digestion is competitive in term of costs and efficiencies as compared to other biomass energy forms including heat, synthesis gases, and ethanol (Chynoweth et al., 2001). Biogas has played an important role in many countries, both developed and developing countries (Abraham et al., 2007). Some countries such as Germany (Scheftelowitz and Thrän, 2016), China (Feng et al., 2012), and India (Schmidt and Dabur, 2014) have greatly gotten benefit from biogas.

Since 2009, Indonesia has received support from Netherlands Government to promote domestic biogas through a program that popularly called BIRU (Biogas Rumah). As a result, application of familysized biogas is increasingly growing. In 2014, BIRU had successfully installed 14,110 domestic digesters (BIRU, 2015). The biogas was used mainly for cooking. A small-scale electricity generation using biogas fuel is one of the most suitable ways to overcome the electricity shortage problem for people in remote areas. Using a small scale independent generator means that no grid is required. From ecological point of view, the engines fueled by the biogas emit much lower amount of $\mathrm{CO}_{2}$ and decreases the global warming potential on our earth due to lower contents of the carbon in the fuel (Mitianiec, 2012).

\subsection{Biogas engine}

A family size power generation using biogas can be completed with small ignition engines by blending (dual mode) for diesel engines or completely (100\%) running with biogas for gasoline or petrol engines. The power can be used to run some appliances as refrigerator, compressor, power generator and irrigation pumps. Tippayawong et al. (2010) reported that biogas can potentially be utilized in a dual fuel operation and performed satisfactorily without any engine hardware modification and no significant problems were observed under long term engine operation. Small generators (about $1 \mathrm{~kW}$ capacity) run on gasoline has been more and more applied in suburban areas by small shops, households or offices to cope up with frequent power black outages. The generator can be operated completely using biogas to overcome electricity scarcity in remote areas. Vaghmashi et al. (2014) concluded that compressed biogas is having good potential to replace petrol. Ayade and Latey (2016) recently reported that blending biogas with petrol at a ratio of $60 \%$ petrol and $40 \%$ biogas (B40) resulted in the increase of thermal efficiency of the engine up to around 37\% as compared to around $26 \%$ of engine with neat petrol. In addition, the B40 blending also decreased brake specific fuel consumption by $8 \%$ in comparison with neat petrol. Ehsan and Naznin (2005) reported their work on power generation using small engine $(1.5 \mathrm{~kW})$ running with $100 \%$ biogas. Even though the brake specific fuel consumption (BSFC) using biogas was comparatively high but peak efficiency was comparable to that of engine using petrol.

Spark ignited gasoline engines may be converted to be able to operate on biogas by changing the carburetor to one that operates on gaseous fuels. The conversion of SI engines to gas fuelling is a simple matter, requiring only the fitting of a simple gas-fuel adaptor and, possibly, hardened valves and valve seats (Jawurek et al., 1987). Recently, Surata et al., (2014) reported a simple conversion of gasoline-fueled single cylinder four stroke engines to run the electric generator using biogas without changing the compression ratio of original spark ignition engine. The engine run stable and was able to generate electricity using $100 \%$ biogas.

\subsection{Biogas Desulfurization}

Biogas contain a trace of compounds harmful for the engine, especially hydrogen sulfide $\left(\mathrm{H}_{2} \mathrm{~S}\right)$. This compound is so corrosive to metal parts in the engine, and must be removed. In addition, combustion of biogas containing $\mathrm{H}_{2} \mathrm{~S}$ produces poisonous sulfur dioxide $\left(\mathrm{SO}_{2}\right)$. When $\mathrm{SO}_{2}$ reacts with water vapor it produces sulfuric acid that corrodes the engine and exhaust pipe. The $\mathrm{SO}_{2}$ also dissolves in engine oil causing the oil to become acidic and lose its lubrication ability (Cherosky, 2012). Electric 
generation using ignition engine requires that biogas must be cleaned so that the $\mathrm{H}_{2} \mathrm{~S}$ content reaches less than 100 ppm (McKinsey-Zicari, 2003). Therefore, biogas treatment is necessary to reduce undesired compounds.

Kobayashi et al. (2012) noted some biological desulfurization including bio-filter processes, the bioscrubber processes, and the process using headspace of the digesters (headspace process). McKinsey-Zicari (2003) used cow-manure compost to remove of hydrogen sulfide from biogas with $\mathrm{H}_{2} \mathrm{~S}$ removal efficiencies over $80 \%$. Su et al. (2013) reported an average $\mathrm{H}_{2} \mathrm{~S}$ removal efficiency $93 \%$ in the livestock biogas using farm-scale bio-filter desulfurization system.

Desulfurization of $\mathrm{H}_{2} \mathrm{~S}$ occur either physically through absorption by water or biologically by microbes. Hydrogen sulfide removal process through absorption is undergoing the dissociation according to following reactions (Horikawa et al., 2004):

$\begin{array}{lll}\mathrm{H}_{2} \mathrm{~S}(\mathrm{~g})+\mathrm{H}_{2} \mathrm{O} & \leftrightarrow & \mathrm{H}_{2} \mathrm{~S}(\mathrm{aq}) \\ \mathrm{H}_{2} \mathrm{~S}(\mathrm{aq}) & \leftrightarrow & \mathrm{H}^{+}+\mathrm{HS}^{-} \\ \mathrm{HS}^{-} & \leftrightarrow & \mathrm{H}^{+}+\mathrm{S}^{2-}\end{array}$

Biological desulfurization process begins with the dissociation of $\mathrm{H}_{2} \mathrm{~S}$. In limited oxygen, the bacteria facilitates redox reactions to generate $\mathbf{S}^{0}$ (Abatzoglou, 2009):

$$
\mathrm{H}_{2} \mathrm{~S} \leftrightarrow \mathrm{H}^{+}+\mathrm{HS}^{-} \text {(disosiation) }
$$

$\mathrm{HS}^{-}+0,5 \mathrm{O}_{2} \rightarrow \mathrm{S}^{0}+\mathrm{OH}^{-}$

Utilization of biogas for electricity generation is not new technology. Family size electricity generation application using biogas, however, is hardly found. The objective of this research, therefore, is to develop a family size biogas-fueled power generation system for simple household utilization. The system should consist of at least three components, namely anaerobic digester to produce biogas, biofilter scrubber to reduce $\mathrm{H}_{2} \mathrm{~S}$ content in the biogas, and small power generating engine running with $100 \%$ biogas.

\section{Materials and Methods}

Figure 1 showed tools and equipment configuration used during the experiment. In short, biogas fuelled electricity power generating system consist of a digester unit to produce biogas, a desulfurization unit to reduce $\mathrm{H}_{2} \mathrm{~S}$, and a power generating engine along with its load.

\subsection{Biogas production and desulfurization}

Biogas was produced from a pilot scale wet digester located at Wastewater Treatment Lab., Department of Agro-industrial Technology, the University of
Lampung. The digester was locally made from fiberglass with a capacity of $5 \mathrm{~m}^{3}$ and working volume of around $4.375 \mathrm{~m}^{3}$. Digester base was slightly tilted in order to facilitate sludge sedimentation cleaning. Substrate used in this work was Palm oil mill effluent (POME) that was taken from cooling pond (second pond) of wastewater treatment plant of Bekri palm oil mill (Central Lampung) and was trucked to the laboratory and then stored in a $5-\mathrm{m}^{3}$ plastic water tank for substrate supply. Table 1 presented substrate characteristic. The substrate was circulated around for about one hour prior to loading into the digester. This step was conducted to make the substrate become homogenized. The substrate was introduced into the digester at a loading rate of 150 liter/day.

Table 1

Characteristic of substrate used in this experiment.

\begin{tabular}{|lc|}
\hline Characteristic & Value \\
\hline $\mathrm{Ph}$ & $4.65-4.98$ \\
$\mathrm{COD}(\mathrm{mg} / \mathrm{L})$ & $57,000-60,400$ \\
$\mathrm{TSS}(\mathrm{g} / \mathrm{L})$ & $0.23-5.44$ \\
$\mathrm{VSS}(\mathrm{g} / \mathrm{L})$ & $0.174-4.232$ \\
\hline
\end{tabular}

Biogas yield was measured using a flowmeter (ITRON ACD G1.6) and stored in a pouch (300 L capacity) for generator engine testing. Biogas piping was equipped with an expansion valve to dry the biogas. The biogas was flown through a bio-filter scrubber column filled with locally made compost to reduce $\mathrm{H}_{2} \mathrm{~S}$ content. The level of $\mathrm{H}_{2} \mathrm{~S}$ before and after purification was measured using a $\mathrm{H}_{2} \mathrm{~S}$ detector (Gastech). Main composition of biogas was analyzed using a gas chromatograph (Shimadzu GC2014) with TCD detector and zinc carbon column. Figure 1 showed tools and equipment configuration used during the experiment.

\subsection{Biogas Desulfurization}

Biogas was purified prior to utilization as engine fuel, using a scrubber filled with biofilter made from locally-produced compost, especially to remove $\mathrm{H}_{2} \mathrm{~S}$. Biogas was flowed through the bottom of a vessel contained biofilter, flowing out through the top. While the biogas is flowing up through the bed of biofilter, it is expected that chemotrophic bacteria separate the sulfur from the biogas. In order to elucidate the biological role of biofilter scrubber in the declining of $\mathrm{H}_{2} \mathrm{~S}$ content, we sent biofilter material to Graduate School of Environment and Information Sciences, Yokohama National University, for microbial quionone analysis. Isoprenoid quinones are lipidsoluble substances found in almost all species of organisms. Quinones play important biological role for their functions as electron carriers in respiratory chains and photosynthetic electron transport systems coupled to proton translocation (Hirashi et al., 1999). Quinone analysis can be used to effectively quantify microbial community. Detailed procedure of quinone analysis has been described by Hasanudin et al. (2005). 
Citation: Haryanto, A., Marotin, F., Triyono, S., and Hasanudin, U. (2017), Developing A Family-Size Biogas-Fueled Electricity Generating System. International Journal of Renewable Energy Development, 6(2), 111-118, https://doi.org/10.14710/ijred.6.2.111-118

$\mathrm{P}$ a g e | 114
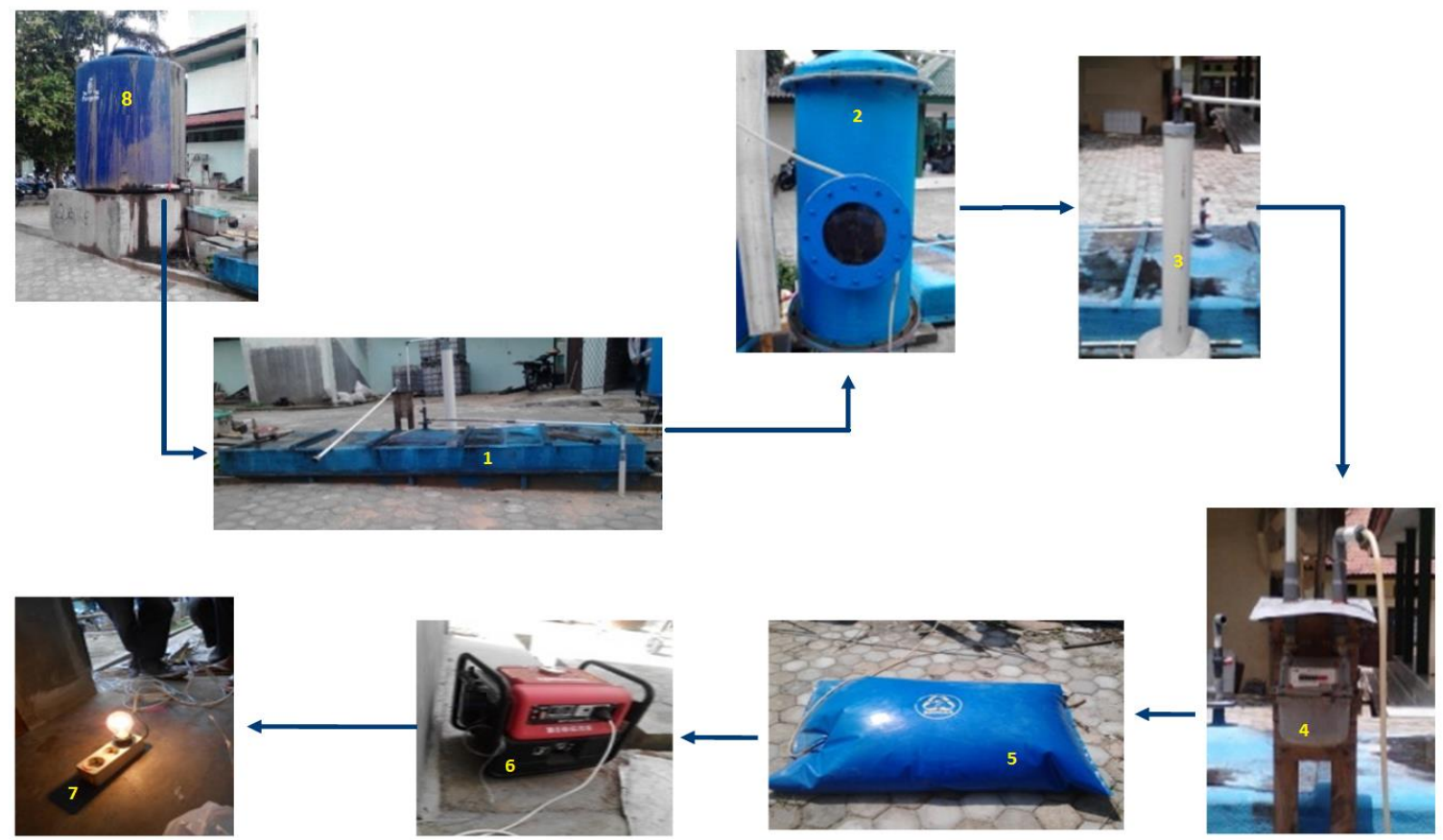

Figure 1. Tools and equipment used in the study, from biogas production to generator testing: 1 . Wet anaerobic digester $\left(5 \mathrm{~m}^{3}\right) ; 2 . \mathrm{Bio}^{-}$ filter scrubber; 3. Pressure expansion (dryer); 4. Biogas flowmeter; 5. Biogas storage; 6. Generator engine 750-W; 7. Load; 8. Substrate storage tank $\left(5 \mathrm{~m}^{3}\right)$.

\subsection{Engine Testing}

Generator engine was procured from PT. SWEN Bogor, Indonesia. It was a four-stroke spark ignition (SI)engine that has been modified to using biogas fuel with a capacity of $750 \mathrm{~W}$ (Table 2). As depicted in Figure 1, the biogas was stored in a pouch prior to using for the engine testing.

Table 2

Biogas engine specification used in the experiment.

\begin{tabular}{ll}
\hline Specification & \multicolumn{1}{c}{ Value } \\
\hline Engine type & $\begin{array}{l}\text { air cooled, } 4 \text { stroke, single } \\
\text { cylinder }\end{array}$ \\
Displacement & $79.7 \mathrm{~cm}^{3}$ \\
Rated power output & $750 \mathrm{VA}$ \\
Maximum power output & $850 \mathrm{VA}$ \\
Voltage output & $220 \mathrm{~V}$ \\
Frequency & $50 \mathrm{~Hz}$ \\
\hline
\end{tabular}

Genset testing was performed by varying the load from 100 to $700 \mathrm{~W}$ and was replicated 3 times for each load. Several incandescent lamps and iron set in parallel arrangement were used as variable electric loads. Engine parameters to be evaluated are brake power $\left(P_{\mathrm{b}}\right)$, specific fuel consumption $(S F C)$, and thermal efficiency $\left(\mathrm{n}_{\mathrm{TH}}\right)$. All of these parameters are calculated as in the following (Reddy et al., 2016):

$P_{\mathrm{b}}=V \times I$

$S F C=F C / P_{\mathrm{b}}$
$\mathrm{\eta}_{\mathrm{TH}}=\frac{3600 \times P_{b}}{F C \times L H V} \times 100$

where $V$ is the voltage developed by the generator $(\mathrm{V})$, $I$ is the current produced by the generator (A), $F C$ is the fuel (biogas) consumption rate $(\mathrm{L} / \mathrm{h})$, and $L H V$ is the lower heating value of the biogas (MJ/L). The voltage is measured using a multitester Sanwa YX360TRF) and electric current is measured using a digital clamp meter (Kyoritsu 2007A). Biogas consumption rate was measured using the same gas flow meter.

\section{Results and Discussion}

\subsection{Biogas production and desulfurization}

The results showed that wet anaerobic digestion system was capable to produce biogas at a total of 1910 L/day (Table 3). Recently, Haryanto et al. (2017) also reported that a $6-\mathrm{m}^{3}$ fixed dome family size cowdung anaerobic digester with 6 head of cows was able to produce biogas at a rate of $2164 \mathrm{~L} /$ day. This implied that family size anaerobic digesters produce biogas at about the same amount, namely 361 $\mathrm{L} /$ day $/ \mathrm{m}^{3}$ to $382 \mathrm{~L} /$ day $/ \mathrm{m}^{3}$ of digester capacity.

Biogas composition (Table 4) showed a relatively normal value of methane $\left(\mathrm{CH}_{4}\right)$, which is $56.48 \%$ by volume. This value indicated that biogas has a fairly good quality and easy to burn. Using low heating value $191.76 \mathrm{kcal} / \mathrm{mole}$ for methane or $35.82 \mathrm{MJ} / \mathrm{Nm}^{3}$ (Capocelli and de Falco, 2016), the biogas has calorific value of $20.23 \mathrm{MJ} / \mathrm{Nm}^{3}$. 
Table 3

Biogas yield and $\mathrm{H}_{2} \mathrm{~S}$ content of biogas before and after biofiltration.

\begin{tabular}{|l|c|c|}
\hline Parameter & Unit & Value \\
\hline Biogas yield & L/day & 1910 \\
$\mathrm{H}_{2} \mathrm{~S}$ content before filtration & $\mathrm{ppm}$ & 400 \\
$\mathrm{H}_{2} \mathrm{~S}$ content after filtration & $\mathrm{ppm}$ & 9 \\
$\mathrm{H}_{2} \mathrm{~S}$ removal & $\%$ & 98 \\
\hline
\end{tabular}

Table 4

Composition of biogas.

\begin{tabular}{lc}
\hline Composition & Value \\
\hline Methane $\left(\mathrm{CH}_{4}\right)$ & 56.48 \\
Nitrogen $\left(\mathrm{N}_{2}\right)$ & 3.33 \\
Carbon Dioxide $\left(\mathrm{CO}_{2}\right)$ & 39.31 \\
Others & 0.88 \\
\hline
\end{tabular}

Biogas produced from anaerobic digestion mainly constituted of methane and carbon dioxide. Trace compounds in the biogas includes ammonia, water, nitrogen, and notably hydrogen sulphide $\left(\mathrm{H}_{2} \mathrm{~S}\right)$. Hydrogen sulphide is produced from the mineralization of organic compounds containing sulphur, such as proteins, by sulphate reducing bacteria. As presented in Table 3, biogas produced in this experiment had a relatively high $\mathrm{H}_{2} \mathrm{~S}$ content (400 ppm) which is harmful for the engine. Hydrogen sulfide is corrosive to metal parts in the engine that must be removed. In addition, combustion of biogas containing $\mathrm{H}_{2} \mathrm{~S}$ produces poisonous sulfur dioxide $\left(\mathrm{SO}_{2}\right)$. When $\mathrm{SO}_{2}$ reacts with water vapor it produces sulfuric acid that corrodes the engine and exhaust pipe. The $\mathrm{SO}_{2}$ also dissolves in engine oil causing the oil to become acidic and lose its ability to lubricate (Cherosky, 2012). Using bio-filter scrubber, the $\mathrm{H}_{2} \mathrm{~S}$ content was reduced to $9 \mathrm{ppm}$ which is far below the minimum value for engine application (100 ppm). Our results showed that bio-filter scrubber effectively reduced $\mathrm{H}_{2} \mathrm{~S}$ level by $98 \%$. This may be resulted from sulphur utilizing bacteria present in the compost used as bio-filter scrubber.

Results from quinone analysis of fresh compost used for biosrubber material is presented in Figure 2. The figure revealed that microorganisms in the compost contain quinone structures of menaquinone (MK) and ubiquinone (UQ). Menaquinone with 6 to 8 isoprene units, namely MK-6, MK-7 and MK-8 respectively, and ubiquinone with 8 and 10 isoprene units, namely UQ-8 and UQ-10, dominated quinone structure of the bacteria existing in the compost. These bacteria may take an important role in the desulfurization process through oxidation and reduction as well. Within anaerobic conditions, the MK-6 might correspond with sulfate reducing bacteria that derive energy by anaerobic respiration reducing sulfate compounds (Hasanudin et al., 2004). Some sulfur-reducing bacteria such as Desulfovibrio desulfuricans, D. vulgaris and D. gigas have been reported contain major menaquinone of MK-6 (Collins and Widell, 1986). Examples of sulfur-reducing bacteria with major menaquinone MK-7 include Desulfococcus multivorans, Desulfobacter curvatus, Desulfosarcina variabilis, and Desulfonema limicofa (Widdel and Bak, 1992); while Desulfuromonas acetoxidans and Desulfuromonas acetexigens having menaquinone MK-8 (Kuever et al., 2005). Ubiquinone with isoprene number of 8 (UQ-8) and 10 (UQ-10) may explained the existence of sulfur-oxidizing bacteria. Bacteria from Thiobacillus genera (T. thioparus, T. denitrificans, T. aquaesulis) are of sulfur-oxidizing groups those have been identified as containing major ubiquinone UQ-8; whilst Thiobacillus novellus and T. perometabolis, have quinone structure of UQ-10 (Robertson and Kuenen, 2006).

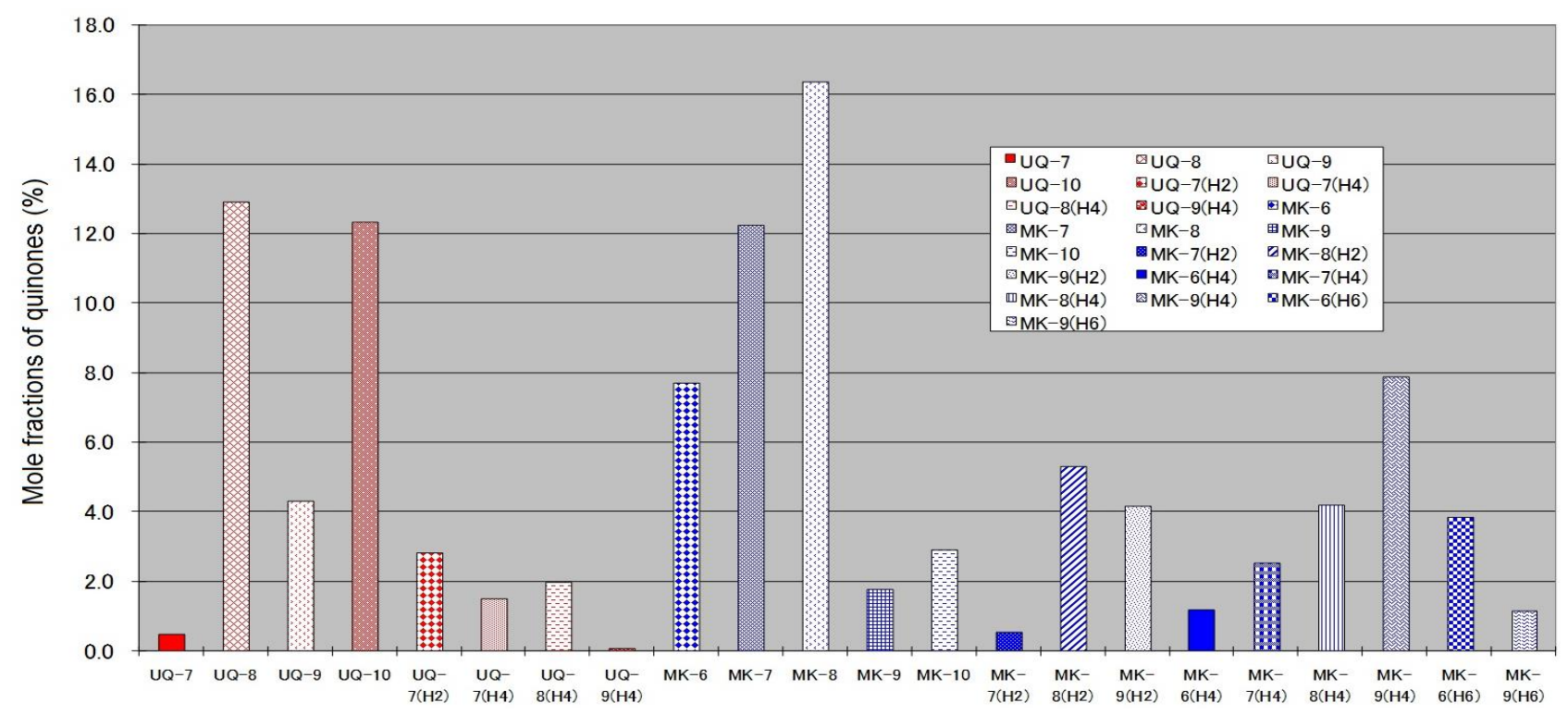

Figure 2. Microbial quinone distribution obtained from fresh compost used for biofilter scrubber. 
Citation: Haryanto, A., Marotin, F., Triyono, S., and Hasanudin, U. (2017), Developing A Family-Size Biogas-Fueled Electricity Generating System. International Journal of Renewable Energy Development, 6(2), 111-118, https://doi.org/10.14710/ijred.6.2.111-118

$\mathrm{P}$ a g e | 116

\subsection{Engine performance}

Biogas utilization as fuel for generator engine showed a good performance during the test, which reached a total of 210 minutes. It was noted, however, that biogas should be utilized as soon as it is produced. The biogas that was stored in the pouch about five days resulted in unstable combustion which caused a problem for the generator. This was probably caused by diffusion of methane through the pouch skin. The results also showed that fuel consumption (FC) ranged from $400.8 \mathrm{~L} / \mathrm{h}$ to $434.4 \mathrm{~L} / \mathrm{h}$ biogas with average of $415.3 \mathrm{~L}$ (Figure 3). This implied that the digester in this experiment is able to serve for about 4-5 hours. Figure 3 also revealed that biogas consumption slightly increased linearly with load. The linear relation of biogas consumption towards load was also reported by Ehsan and Naznin (2005). They reported the biogas consumption of $1.5-\mathrm{kW}$ engine was about $2.0 \mathrm{~kg} / \mathrm{h}$ at a load of $800 \mathrm{~W}$. Using biogas density of $1.12 \mathrm{~kg} / \mathrm{m}^{3}$ (Reddy et al., 2016), the figure corresponds to around $1786 \mathrm{~L} / \mathrm{h}$. Biogas consumption of our result was significantly lower. The different of engine capacity $(750 \mathrm{~W}$ vs. $1500 \mathrm{~W})$ might be the reason of this discrepancy.

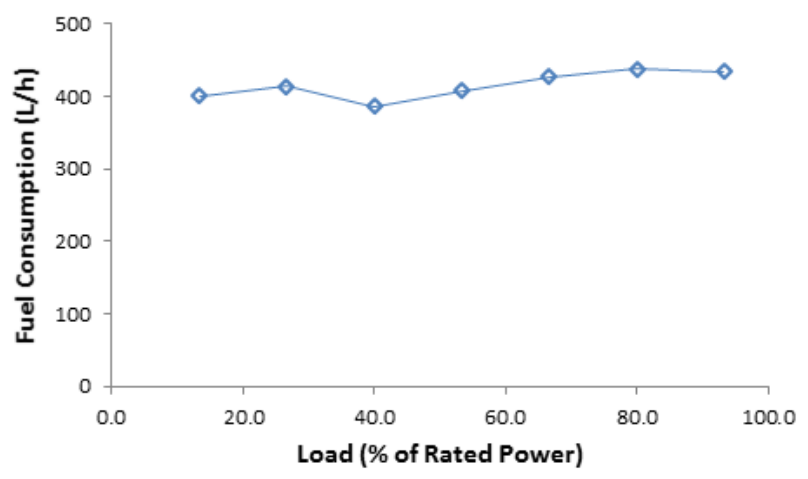

Figure 3. Relation of load and biogas consumption.

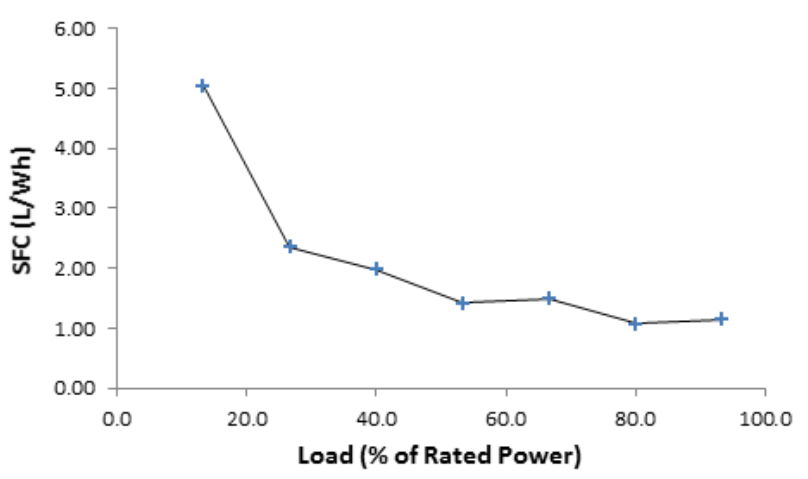

Figure 4. Effect of load on the specific biogas consumption.

Another useful parameter is the specific fuel consumption $(S F C)$ which is fuel flow rate per unit of power output. It measures how efficiently an engine is using the fuel supplied to produce useful work. Figure
4 showed that $S F C$ was high at low electricity load, then decreased sharply to a minimum near the rated capacity. It can also be observed that the magnitude of the electric load affected the SFC. Our results revealed $S F C$ values ranged from $5.05 \mathrm{~L} / \mathrm{Wh}$ at a load of $100 \mathrm{~W}(13.3 \%)$, sharply decreased $2.35 \mathrm{~L} / \mathrm{Wh}$ at a load of $200(26.7 \%)$ and gradually decreased to 1.15 $\mathrm{L} / \mathrm{Wh}$ at a load of $700 \mathrm{~W}(93.3 \%)$. Similar pattern of the relationship between $S F C$ of the engine generator and load applied to the generator was found in the work reported by others (Ehsan and Naznin, 2005; Reddy et al., 2016). Ehsan and Naznin (2005) studied the use of biogas with $\mathrm{CH}_{4}$ content varies from $55 \%$ to $75 \%$ to run $1.4-\mathrm{kW}$ four stroke spark ignited power generator engine. For biogas with $55 \% \mathrm{CH}_{4}$ (similar to our case), they reported specific fuel (biogas) consumption ranged from around $13900 \mathrm{~g} / \mathrm{kWh}$ (around $12.4 \mathrm{~L} / \mathrm{Wh}$ ) at a load of $100 \mathrm{~W}(7.14 \%)$ decreased to $4034 \mathrm{~g} / \mathrm{kWh}$ (around $3.36 \mathrm{~L} / \mathrm{kWh}$ ) at 370 $\mathrm{W}(26 \%)$ and to $2413 \mathrm{~g} / \mathrm{kWh}(2.01 \mathrm{~L} / \mathrm{kWh})$ at $800 \mathrm{~W}$ (57\%) of load. In general, increasing the load close to the engine capacity resulted in the decreasing specific fuel consumption. Under low load the $S F C$ is high because the mechanical efficiency is low. At high engine load (close to the rated power), the combustion is improved due to higher temperature (inside the cylinder) after successive working of engine at high load which improves fuel atomization and fuel-air mixing process as well.

Thermal efficiency ( $\left.\eta_{\mathrm{TH}}\right)$, on the contrary, increased with the load (Figure 5). This means that the engine produce the best performance at loads close to the maximum capacity. At a load of $600 \mathrm{~W}(80 \%)$, the hourly specific consumption of biogas was $0.73 \mathrm{~L} / \mathrm{W}$ with an effective thermal efficiency of 30\%. This result was in close agreement with the work of Himabindu and Ravikhrisna (2014) which reported a prototype of small power generator running on entirely biogas containing $65 \%$ methane. The prototype showed good performance in the power range of around $1 \mathrm{~kW}$ with maximum overall efficiency of $19 \%$ and approximated brake thermal efficiency between 25 to $37 \%$.

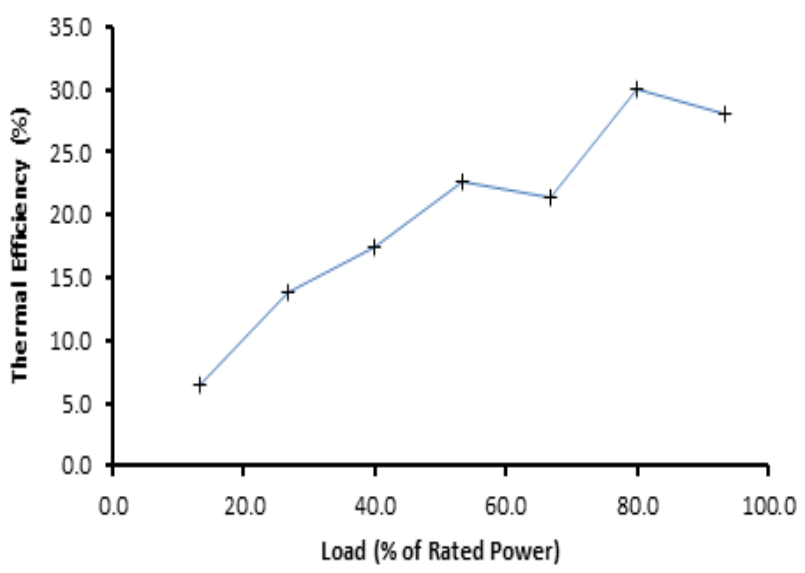

Figure 5. Effect of load on the thermal efficiency. 


\section{Conclusion}

A family size biogas-fueled power generating system consisting of important units such as an anaerobic digester unit, a biofilter scrubber, and a four-stroke generator engine has been developed. The biofilter scrubber effectively reduced $\mathrm{H}_{2} \mathrm{~S}$ content with removal efficiency of $98 \%$. The engine successfully ran using $100 \%$ biogas with $\mathrm{CH}_{4}$ content of $56.48 \%$. Average biogas consumption was $415.3 \mathrm{~L} / \mathrm{h}$ in a range of 400.8 to $434.4 \mathrm{~L} / \mathrm{h}$ and increased with load. Load also affected specific fuel consumption and thermal efficiency. Specific fuel consumption was around 5.05 $\mathrm{L} / \mathrm{Wh}$ at a load of $100 \mathrm{~W}$ and $1.15 \mathrm{~L} / \mathrm{Wh}$ at a load of $700 \mathrm{~W}$. The highest thermal efficiency was $30.0 \%$ and occurred at a load of 600 watt ( $80 \%$ load).

\section{Acknowledgment}

This work was supported by DGHE (Directorate General of Higher Education), Ministry of National Education through Strategis Nasional (STRANAS) research scheme. Contract: 419/UN26/8/LPPM/2016 (June 6, 2016). Quinone analysis was made possible thanks to the generosity of Prof. Koichi Fujie, Japan Graduate School of Environment and Information Sciences, Yokohama National University, Japan. The authors express their gratitude and appreciation to Prof. Fujie.

\section{References}

Abatzoglou, N. (2009) A review of biogas purification processes. Biofuels, Bioproduct, Biorefinery, 3, 42-71.

Abraham, E.R., Ramachandran, S., Ramalingam, V. (2007) Biogas: Can it be an important source of energy? Environmental Science and Pollution Research, 14(1), 67-71.

Ayade, M. and Latey, A.A. (2016) Performance and emission characteristics of biogas-petrol dual fuel in SI engine. International Journal of Mechanical Engineering and Technology, 7(2), 45-54.

BIRU (Biogas Rumah). (2015) Annual Report Indonesia Domestic Biogas Programme January - December 2014.

Capocelli, M. and de Falco, M. (2016) Enriched methane: A ready solution for the transition towards the hydrogen economy. In Enriched Methane: The First Step Towards the Hydrogen Economy (Editors: M. de Falco and A. Basile). Springer International Publishing, Switzerland, 1-21.

Chandra, R., Takeuchi, H., Hasegawa, T. (2012) Methane production from lignocellulosic agricultural crop wastes: a review in context to second generation of biofuel production. Renewable Sustainable Energy Review, 16, 1462-1476.

Cherosky, P.B. (2012) Anaerobic digestion of yard waste and biogas purification by removal of hydrogen sulfide. Master Thesis. Graduate Program in Food, Agricultural and Biological Engineering, Ohio State University.

Chynoweth, D.P., Owens, J.M., Legrand, R. (2001) Renewable methane from anaerobic digestion of biomass. Renewable Energy, 22(3), 1-8.

Collins, M.D. and Widdel, F. (1986). Respiratory quinones of sulphate-reducing and sulphur-reducing bacteria: A systematic investigation. Systematic and Applied Microbiology, 8, 8-18.

Directorate General of Electricity, (2016) Statistik
Ketegalistrikan 2015 (2015 Electricity Statistic). Ministry of Energy and Mineral Resources: 26.

Ehsan, M. and Naznin, N. (2005) Performance of a biogas run petrol engine for small scale power generation. Journal of Energy \& Environment, 4, 1-9.

Feng, Y., Guo, Y., Gaihe, Y., Qin, X., Song, Z. (2012) Household biogas development in rural China: On policy support and other macro conditions. Renewable Sustainable Energy Review, 16, 5617-5624.

Haryanto, A., Cahyani, D., Triyono, S., Murdapa, F., and Haryono, D. Economic benefit and greenhouse gas emission reduction potential of a family-scale cowdung anaerobic biogas digester. International Journal of Renewable Energy Development, 6(1), 29-36.

Hasanudin, U., Fujita, M., Fujie, K., Koibuchi, Y. (2005) Dynamic changes in environment condition and microbial community structure in trench and flat seabed sediments of Tokyo bay, Japan. Journal of Water Science and Technology, 52(9), 107-114.

Hasanudin, U., Fujita, M., Kunihiro, T., Fujie, K., Suzuki, T. (2004) The effect of clams (Tapes philippinarum) on changes in microbial community structure in tidal flat sediment mesocosms, based on quinone profiles. Journal of Ecological Engineering, 22(3), 185-196.

Himabindu, M. and Ravikhrisna, R.V. (2014) Performance assessment of a small biogas-fueled power generator prototype. Journal of Scientific and Industrial Research, 73, 781-785.

Hiraishi, A. (1999) Isoprenoid quinones as biomarkers of microbial populations in the environment. Journal of Bioscience and Bioengineering, 88(5), 449-460.

Horikawa, M.S., Rossi, F., Gimenes, M.L., Costa, C.M.M., da Silva, M.G.C. (2004) Chemical absorption of $\mathrm{H}_{2} \mathrm{~S}$ for biogas purification. Brazilian Journal of Chemical Engineering, 21(03), 415 - 422

Jawurek, H.H., Lane, N.W., Rallis, C.J. (1987) Biogas/petrol dual fuelling of SI engine for rural third world use. Biomass, 13(2), 87-103.

Kabir, H., Yegbemey, R.N., Bauer, S. (2013) Factors determinant of biogas adoption in Bangladesh. Renewable Sustainable Energy Review, 28, 881-889.

Kobayashi, T., Li, Y-Y., Kubota, K., Harada, H., Maeda, T., Yu, H-Q. (2012) Characterization of sulfide-oxidizing microbial mats developed inside a full-scale anaerobic digester employing biological desulfurization. Applied Microbiology and Biotechnology, 93, 847-857.

Kuever, J., Rainey, F.A. Widdel, F. Genus I. (2005) Desulfuromonas Pfennig and Biebl 1977, 306 ${ }^{\mathrm{AL}}$. In Bergey's Manual of Systematic Bacteriology. Vol. Two: The Proteobacteria. Part C: The Alpha-, Beta-, Delta-, and Epsilonproteobacteria. (Editors: D.J. Brenner, N.R. Krieg, J.T. Staley). Springer Science+Business Media, Inc., 233 Spring Street, New York: 1005-1010.

McKinsey-Zicari, S. (2003) Removal of hydrogen sulphyde using cow manure compost. Master Thesis. Department of Biological and Environmental Engineering, Cornel University.

Mitianiec, W. (2012) Factors determining ignition and efficient combustion in modern engines operating on gaseous fuels. Internal Combustion Engines (Lejda, K. and Woś, P., editors). InTech, Janeza Trdine 9, 51000 Rijeka, Croatia: 334.

Power in Indonesia. (2015) Investment and taxation guide. $3^{\text {rd }}$ edition. Available from www.pwc.com/id (January 11, 2016)

PLN. (2015) Electricity Tariff Adjustment of December 2015. www.pln.co.id/wp-content/uploads/2015/11/TA-Desember2015.pdf (January 11, 2016)

Reddy, K.S., Aravindhan, S., Mallick, T.K. (2016) Investigation of performance and emission characteristics of a biogas fueled electric generator integrated with solar concentrated photovoltaic system. Renewable Energy, 92, 233-243. 
Citation: Haryanto, A., Marotin, F., Triyono, S., and Hasanudin, U. (2017), Developing A Family-Size Biogas-Fueled Electricity Generating System. International Journal of Renewable Energy Development, 6(2), 111-118, https://doi.org/10.14710/ijred.6.2.111-118

$\mathrm{P}$ a g e | 118

Robertson, L.A. and Kuenen, J.G. (2006) The Genus Thiobacillus. In The Prokaryotes: A Handbook on the Biology of Bacteria. Vol. 5: Proteobacteria: Alpha and Beta Subclasses (Editors: M. Dworkin, S. Falkow, E. Rosenberg, K.-H. Schleifer, E. Stackebrandt). Springer Science+Business Media, Inc., 233 Spring Street, New York. Third Edition: 812-827.

Scheftelowitz, M. and Thrän, D., 2016. Unlocking the energy potential of manure - An assessment of the biogas production potential at the farm level in Germany. Agriculture, 6, 1-20.

Schmidt, T. S. and Dabur, S. (2014) Explaining the diffusion of biogas in India: a new functional approach considering national borders and technology transfer. Environmental Economics and Policy Studies, 16, 171-199.

Su, J-J., Chang, Y-C., Chen, Y-J., Chang, K-C., Lee, S-Y. (2013) Hydrogen sulfide removal from livestock biogas by a farmscale bio-filter desulfurization system. Water Science and Technology, 67(6), 1288-1293.
Surata, I.W., Nindhia, T.G.T., Atmika, I.K.A., Negara, D.N.K.P., Putra, I.W.E.P. (2014) Simple conversion method from gasoline to biogas fueled small engine to powered electric generator. Energy Procedia, 52, 626-632.

Tippayawong, N., Promwungkwa, A., Rerkkriangkrai, P. (2010) Durability of a small agricultural engine on biogas/diesel dual fuel operation. Iranian Journal of Science and Technology, Transactions B, 34(B2), 167-177.

Vaghmashi, J.D., Shah, D.R., Gosai, D.C. (2014) An experimental study of petrol engine using compressed biogas as a fuel. International Journal for Scientific Research \& Development, 2(04), 2321-0613.

Widdel, F. and Bak, F. (1992) Gram-negative mesophilic sulfatereducing bacteria. In The Prokaryotes: a handbook on the biology of bacteria: ecophysiology, isolation, identification, applications, Vol. 4. (Editors: A. Balows, H.G. Triiper, M. Dworkin, W. Harder, and K.-H. Schleifer). $2^{\text {nd }}$ ed. Springer Science+Business Media, Inc., 233 Spring Street, New York: 3370 . 